\title{
Increasing Senior High School Students' Ability In Speaking English Through Contextual Storytelling Method
}

\author{
Meyke Machrita Mamahit \\ English Teacher, Senior High School State 7 Manado \\ Email: meykemachritamamahit@gmail.com
}

(Received: October-2017; Reviewed: Nopember-2017; Accepted: November-2017; Published: December-2017)

C2017 -EST Graduate Program Universitas Negeri Makassar. This is an article with open access under license CC BY-NC-4.0 (https://creativecommons.org/licenses/by-nc/4.0/ ).

\begin{abstract}
This research aimed (1) to increase the ability of students XII Grade Science 6 Senior High School state 7 Manado in speaking English through contextual storytelling method, (2) to increase the motivation and interest of students XII Grade Science 6 Senior High School state 7 Manado in speaking English through contextual storytelling method. This research is Classroom Action Research. The population was 325 students and the sample was 30 students. The research data was collected using performance test of cycle 1,2, 3 and questionnaire. The research results indicated that the use of contextual storytelling method in learning English significantly increased the ability, interest and motivation of students XII Grade Science 6 Senior High School state 7 Manado in speaking English. The percentage of students who achieved the minimum score increased from $60 \%$ in the first cycle became $70 \%$ in the second cycle, and increased $90 \%$ in the third cycle. The students' interest and motivation in speaking English increased from $70 \%$ in first cycle became $80 \%$ in the second cycle and became $90 \%$ in the third cycle.
\end{abstract}

Keywords: speaking; English ability; contextual storytelling method

\section{INTRODUCTION}

Education is very important element to increase the quality of human resources, because education is the vehicle of human resources to develop his potential. The human quality can be increased through education. Education is the exert of someone to achieve the goal made.

School has roles and responsibility to develop all aspects of students' personality through educational process in school. Teaching and learning activity are the main function of school and the most strategy effort to achieve the education institutional goal, especially to increase the students' ability in cognitive, psychomotor, and affective, so that the education done can produce good results in test score and other learning achievement.

Sutaria (1998:128) said that "The quality of the school output is only as good as the quality of the teacher". The role of teacher is very important to transform the educational input and through the process changes the input become output product, good quality of service and information, that will continue to the good quality of outcome.

That is why it is hoped that the teacher can increase his potential and creativity in doing learning activity in the classroom as the effort to increase the students' learning achievement.

According to Tilaar $(1999: 104)$ that "The increasing quality of education depends on many things, especially the quality of teacher."

Teacher is the agent of change. Without any changes and increasing quality of teacher, it is impossible the changes can happen or the quality of school increased especially students.

The low work performance of teacher influences the students' learning quality, and of 
course it will give impact to the low of students' learning achievement.

Teacher is demanded to master knowledge, skill, personal character, social, and motivation so that in transferring knowledge, students can get and mastering the knowledge optimal and they have good attitude and behavior.

Nana Sudjana (2002:42), in her book "Dasar-Dasar Proses Belajar Mengajar, said that: $76,6 \%$ of students learning result is influenced by teacher's performance: teacher's ability in teaching participates 32,43\%, mastering the learning material participates $35,57 \%$ and teacher' attitude to the subject gives contribution $8,60 \%$.

Language as communication vehicle plays an important role in developing students' intellectual, social, and emotional. Through language students can express their idea, feeling, analyzing and imagining, reflecting their experiences and others and also participate actively in society as the user of language.

Speaking is one of English skills, beside listening, reading and writing. The purpose of learning speaking skill is to make students have English speaking skill in communicating to express idea, opinion and feeling to others or group of people as oral, face to face or with long distance.

Wilkin in Oktarina (2002) stated that speaking skill is the ability to arrange sentences because communication happen through sentences to perform the difference various attitude in difference society.

When the students join the speaking English learning in the classroom, they hope after learning process finish at least they have English speaking skill to communicate with their friend, teacher or others although with very simple words as the effort to express idea, thinking, feeling as oral in daily life.

What the students hope do not like in reality, the students' ability in speaking English is low. The students do not interest in learning speaking English and consider that it is difficult to study English especially speaking skill.

In this case they do not use English as tools of communication like what they hope before. It is showed by the document data of students' learning result of grade XII Science 6 Senior High School State 7 Manado in odd Semester 2012/2013 with 30 students in pre cycle, $50 \%$ of them that is 15 students do not achieve minimal score 75 .

The problem of low English speaking competence is caused by some factors, as: the limit of time to study in the classroom, the less of learning facilities, and the teacher who do not understand how to apply curriculum or curriculum in action that caused is not suitable in choosing the right learning method to achieve the certain competence.

The applying of conventional method in learning activity like speech method do not result active, innovative, creative, effective and enjoyable learning process so that the students are difficult to absorb the material given, even they are not able to construct their concept and it causes they are not brave enough to speak English in expressing their idea, feeling and opinion.

The applying of group discussion is not able to involve every student in active, innovative, creative, effective and enjoyable learning process. Just certain student who involve actively in interactive discussion process. The consequence is there are some students fail to develop their ability to speak English.

Hilda Karli (2002:6) stated that The low result of students' achievement is caused by the dominant use of conventional method in learning as speech method, so that the students do not construct the concept that they understand better. That is why they misunderstand the concept that often happen to students.

Learning approach which has relevant with increasing students' competence in speaking English is learning with using contextual approach. The background of appearing the contextual approach is most of students do not connect every learning activity so that it causes they are difficult to master English Speaking skill.

National Education Department (2002) which was taken by Herawati (2003:17), stated that contextual approach is learning concept which help teacher to connect between material which is taught with real world situation of students and motivate the students to connect between knowledge that they have with the applying in their life as the member of family and society.

According to Trianto (2007:103) contextual approach in daily applying involve 
seven main components, they are: constructivism, asking, inquiry, society learning, model, evaluation, and authentic.

Contextual storytelling is used in speaking English learning process as the effort to create active, innovative, creative, effective and enjoyable learning process to increase the students' ability in speaking English to express feeling, thinking, and opinion in their daily life.

Chuck Larkin (1997) storytelling is speaking art or storytelling tells a story or an imaginative story in front of many people, usually face to face is (to differentiate with the film or drama performance in the meaning of storytelling generally).

Learning English with contextual storytelling is assumed that it can increase the students' ability in speaking English. Based on it the researcher is interest to make research with the title "Increasing Senior High School Students' Ability in Speaking English Through Contextual Storytelling Method.”

Based on the background above, the problems of this research are: 1) Is the applying of Contextual Storytelling method in learning can increase the speaking ability of students on grade XII Science 6 Senior High School State 7 Manado ?., 2) Is the applying of Contextual Storytelling method in learning can increase the learning motivation of students on grade XII Science 6 Senior High School State 7 Manado ?.

Based on the problem research, the purposes of this research are: 1) To increase the ability of students on grade XII Science 6 Senior High School State 7 Manado in speaking English through Contextual Storytelling method., 2) To increase the learning motivation of students on grade XII Science 6 Senior High School State 7 Manado in speaking English through Contextual Storytelling method.

\section{METHOD}

The population in this research is students on grade XII Senior High School State 7 Manado, odd semester 2012/2013, total Population 325 students. Sampel is taken from grade XII Science 6 Senior High School State 7 Manado, total 30 students.

This research is Classroom Action Research (CAR). CAR is action research with the purpose to improve the quality of learning in classroom in form of self reflective activity done by the actor of action to improve the rationality and justice about education practice, understanding, situation where that practice is done (Kunandar, 2008:45-46).

This research uses cycle model according to Kemmis and Me Taggart, that the action is done as repetition and continuity. It means that if the action is repeated more times, the result will be more better or the achievement result will increase. This research consists of 3 cycles, with the steps are planning, action, observation, and reflection.

The instrument used in this research to collect data are: 1) Post tes result of every cycle to measure the students' achievement result in speaking English test, 2) students' self evaluation in contextual storytelling learning process belajaran contextual storytelling, 3) observation result during the learning process done by other teacher as observer, 4) note or field note to collect the teacher' reflection data and the changing happen in learning, 5) questionnaire is used to get percentage of students who are interest and not in applying contextual storytelling method in speaking English learning.

The technique of data analyzes in this research is: 1) data is taken from performance test result of cycle 1, 2, and 3 to get cognitive, psychomotor, and affective score and to get percentage of students who has achieved the minimum score or not yet and to get the mean score, 2) data is taken from questionnaire to get the percentage of students who interest or not interest in learning by applying contextual storytelling with the steps: 1) grouping the total students who interest and not, 2) count the percentage of students who interest and not with the formula as follow:

$$
\begin{aligned}
& P \quad=\frac{f}{n} \times 100 \% \\
& \text { Explanation: } \\
& P \quad=\text { Answering percentage } \\
& \mathrm{f} \quad=\text { Frequency of students who answer } \\
& \mathrm{n} \quad=\text { the total of responder } \\
& 100 \% \quad=\text { even number }
\end{aligned}
$$

\section{RESULT AND DISCUSSION}

\section{Result}

Learning result is taken after joining the learning process by using contextual storytelling method with the material is narrative text and the minimal score is 75 . Kind of evaluation is 
performance test, it is done 3 times for each cycle after learning process.

\section{Cycle I}

The beginning of learning process is brain storming to dig how far the students understand the material that will be given to them by giving various imaginative story that they have known and asking about the characteristics of the story. Good responds and full of spirit they answer the questions because the story is familiar with them. Next step explaining about definition, the communicative purpose, generic structure, general feature and giving others narrative story.

Next step, giving 5 questions to be answer for 15 minutes in group and each group send a representative to answer the question on the whiteboard. Their answers are explained by teacher so that they can make correction to their work. At end, teacher gives them new text to be learned at home.

On the second meeting, teacher checks students' homework and share ideas with them related to their homework. Teacher asks them to work in group to memorize the story. Then each group send a representative to retell the story in front of class.

The score is got by the representative of the group will be the same as the score of all members of group. This system makes the students have spirit and motivation to retell the story better. Teacher becomes motivator and facilitator in learning activity by giving explanation to the students who make mistakes in pronunciation and other problems in speaking.

On the third meeting, giving the students new text with the same topic to be discussed in group and writing the definition of the text, communicative purpose, and generic structure. Teacher checks their result and explaining if finding the mistakes. In group they write again the text by using their words. Next, each group sends a representative to read the summary of the text.

The next activity, each group sends a member to retell the story in front of the class while teacher evaluates them by using a filling form. An observer observes the activities of teacher and students and writing them in the notes. The last, students fill the motivation questionnaire form.

\section{Cycle 2}

The first meeting of the second cycle, teacher becomes the model to retell the story in front of the class with the same idea of story on the first cycle but it was adapted becoming the new imaginative story. Teacher asks the students to find out the difference between the activities of cycle 1 and 2 . Students explain their finding and together with teacher make the conclusion.

Making a new group of students (heterogen) based on the performance score in cycle 1 and ask students to make new story draft, with the same text (narrative text/imaginative story). All members in group cooperate each other actively. Teacher monitors and checks all drafts made by each group while giving correction to the mistakes made.

Students make imaginative story in group based on the draft they have made and interact in English while teacher monitors them. At the end of the activity, teacher gives assignment to the students to memorize the new story that they had made.

On the second meeting, students train to prepare themselves in group to demonstrate in front of the class the new story that they have made for 15 minutes. Each member of group tells the story one by one in front of the class.

Teacher gives score individually based on the rubric evaluation.

On the third meeting, together with the students, teacher discusses the finding problem on cycle 1 and 2 and give explanation to make correction to the next activity.

Teacher shows video about the activity of storytelling done by students in other schools. All students watch the video while analyzing critically from the beginning of the activities to the end. After that all groups discuss about the activities that they have just finished watching. Then a student as the representative of her group acts the activities that she has just watched from video in front of the class.

At the end of the activity, teacher and students make the conclusion and teacher asks the other students to make correction the mistakes made by students during the activities in cycle 2 and noticed by teacher.

\section{Cycle 3}


The first meeting of cycle 3, teacher asks students related with the activities in last meeting. The students answer the questions with full of spirit because they had created characters (players) and the old story that they had adapted with the modern ones according to the situation and condition that they had experienced until nowadays.

Although the first time was very difficult for them to memorize the short story and they were afraid to perform in front of the class delivering the storytelling. But now they are very happy because they can perform relax in front of the class to deliver the storytelling that they have made by themselves after the teacher gives them chance.

Students sit in a new group based on the achievement score result in cycle 2 . Each group looks for imaginative story from internet with different title and to modify it to be a new story(adaptation).

Teacher monitor them and give guidance if they find difficulties especially in choosing the vocabularies and pronunciation. Students communicate in English each other to make a new community. They discuss in their group to prepare themselves in performing the storytelling in front of the class.

Teacher prepares a lottery for the groups to perform. Lottery is made to know whose group will perform first, second, third, and so on in front of the class to deliver the storytelling. The rules stated that all members of the group should perform to deliver the storytelling in front of the class because the teacher will evaluate individually to give score not as a group score. Every member of the group is given chance by the teacher to evaluate someone who perform, together with teacher and observer

The second meeting, just go ahead with the last meeting to perform storytelling in front of the class because there were still students not perform yet. The next activity is all results of evaluation of each group are collected to the teacher to be discussed together.

Then teacher gives instruction and explanation related with the next performing to be done better. At the end of the lesson, teacher gives individual task to all students to look for story from various sources to memorize it.

The activities on the third meeting, students train individually for 15 minutes to prepare performing storytelling in front of the class. One by one the students demonstrate the new story that they arranged at home.

Teacher gives score as individually based on rubric evaluation. Other teacher as observer observe the activities of teacher and students. Then students fill in the questionnaire form. The last activity, teacher and students make the conclusion, ask students to make correction for all mistakes found during cycle 1, 2 and 3. On this cycle, the ability of students to communicate in English becomes better, bravely and fluently enough.

\section{Discussion Cycle 1}

Data of performance test result of cycle 1 , the lowest score is 45 . The highest score is 75 . The mean score of cycle 1 is 65 and Pre-cycle is 50. The percentage of students who achieve minimal score of cycle 1 is $60 \%$ or 18 students, in pre-cycle 5 students or $50 \%$. In this case the scores increased but just a little bit because the percentage of increased just $10 \%$.

This is caused by the students feel strange with the storytelling method. They think English speaking learning is difficult and it is not enjoyable. The motivation and interest in learning are low.

\section{Cycle 2}

The learning process of cycle 2 is interesting because it can make students feel wonder which it is not usual the storytelling performed by teacher as the model. The idea is the same as in cycle 1 but it was adapted becoming the new story. In this cycle students begin to feel interested with the contextual storytelling method. the students The performance test result of cycle 2 increases comparing with cycle 1 , the mean score is 75 , the highest score 85 , the lowest score is 55 . The students who achieve the minimal score increased in cycle 2, they are 21 students or 70 $\%$. Learning result of cycle 2 can be seen in table 1:

Table 1

Data score of Performance Test in Speaking

English Competence of Students Grade XII

Science 6 Senior High School State 7 Manado in cycle 1 and 2

\begin{tabular}{lcc}
\hline Result & Cycle 1 & Cycle 2 \\
\hline Mean & 65 & 75 \\
\hline Lowest score & 45 & 55 \\
\hline
\end{tabular}




\begin{tabular}{|c|c|c|}
\hline Highest Score & 75 & 85 \\
\hline Minimal Score $\quad(\%)$ & $60 \%$ & $70 \%$ \\
\hline Increased result $\quad(\%)$ & $10 \%$ & $10 \%$ \\
\hline
\end{tabular}

The changing result of learning in cycle 1 and 2 can be seen in graphic 1 :

Grafic 1. The Mean Score and Percentage of Students who Achieved Minimal Score in Cycle 1 and 2

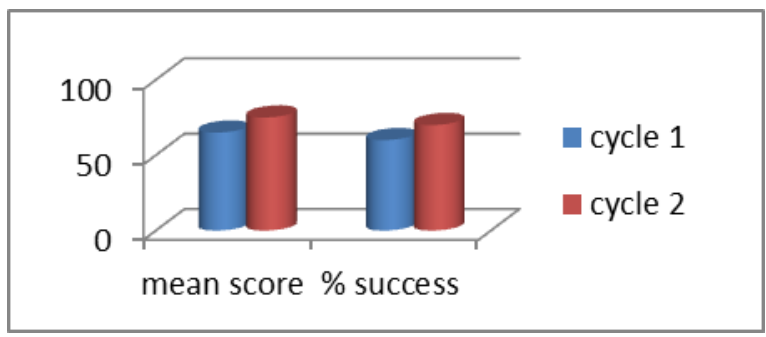

Based on table 1 and graphic 1 we can see that, there is increasing percentage of students who achieve the minimal score from cycle 1 to cycle 2 , it is $10 \%$. It means that speaking English learning by using contextual storytelling method is enjoyed by the students.

\section{Cycle 3}

In this third cycle, students are really enjoy and comfort with speaking English learning process by using contextual storytelling method. Their interest and motivation increase, they have full of spirit and they feel easier in learning speaking English. It is proved by the total students who involved in English active discussion with their friends in group and with the English teacher. It was seldom to see in English learning process before. From this activity teacher can be easy to evaluate directly their actively in speaking English.

In this case the teacher can make enrichment and remedial activity directly without waiting the result of test. At last the teacher and students can really enjoy the speaking English learning process more meaningful. Data score of test result in cycle 2 compare with cycle 3 increases significantly, the mean score is 75 in cycle 2 becomes 80 in cycle 3 . The highest score is 90 and the lowest score is 65 . The students who achieve score minimal in cycle 2 is 21 persons, in cycle 3 is 27 persons. It can be seen on table 2 :

Table 2. Data score of performance test in speaking English competence of students grade XII Science 6 Senior High School State 7 Manado in cycle 2 and 3

\begin{tabular}{lcc}
\hline \multicolumn{1}{c}{ Result } & Cycle 2 & Cycle 3 \\
\hline Mean & 75 & 80 \\
\hline Lowest score & 55 & 65 \\
\hline Highest score & 85 & 90 \\
\hline Success (\%) & $70 \%$ & $90 \%$ \\
\hline Increased Result (\%) & $10 \%$ & $20 \%$ \\
\hline
\end{tabular}

Grafic 2. The Mean Score and Percentage of Students who Achieve Minimal Score in Cycle 2 and 3

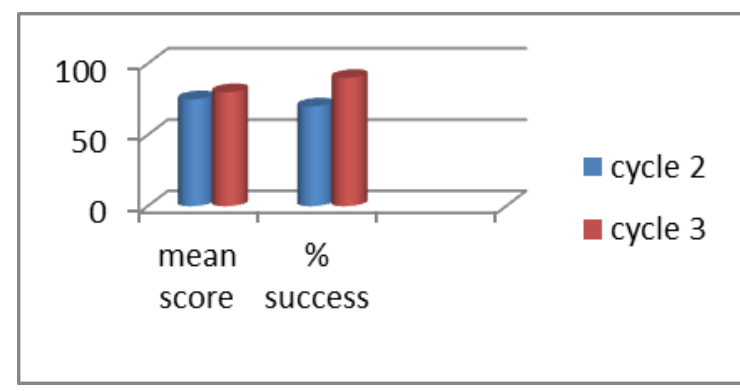

Percentage of students who achieve the minimal score increase from cycle 2 to cycle 3 , it is $70 \%$ from cycle 2 becomes $90 \%$ in cycle 3 . It increases $20 \%$. There are 3 students who do not achieve the minimal score from total 30 students. If we compare score data from cycle 1 to cycle 3 , it increased $30 \%$.

It shows that learning speaking English by using contextual storytelling method can increase the students performance test result grade XII Science 6 Senior High School State 7 Manado.

Table 1 and 2, and grafic 1 and 2 above shows that the mean score from cycle 1 to 3 increased significantly. The percentage of students who achieve minimal score increased significantly from cycle 1 to 3 .

The interest and motivation respond of students can be seen as follows:

In cycle 1 , the percentage of students who give positive respond or interest in learning speaking English is $70 \%$ or 21 students and the rest of 9 students give negative respond or $30 \%$. 
In cycle 2, positive respond of students increased become $80 \%$ or 24 students. The rest of 6 students gave negative respond or $20 \%$, It increased $10 \%$ from cycle 1 .

In cycle 3 respond positive of students increased become $90 \%$ or 27 students and the rest 3 students gave negative respond or $10 \%$.

From the result above we can conclude that learning speaking English by using contextual storytelling method can increase the students motivation and interest in learning speaking English. It can be seen in table 3 and graphic 3, as follows:

Table 3. Percentage of Positive and Negative Respond of Student

\begin{tabular}{lcc}
\hline \multicolumn{2}{l}{ Positive Reaction (\%) } & Negative Reaction (\%) \\
\hline Cycle 1 & $70 \%$ & $30 \%$ \\
\hline Cycle 2 & $80 \%$ & $20 \%$ \\
\hline Cycle 3 & $90 \%$ & $10 \%$ \\
\hline
\end{tabular}

Grafic 3. Percentage of Motivation and Interest Respond of students XII Science 6 Senior High School State 7 Manado in Speaking English Learning

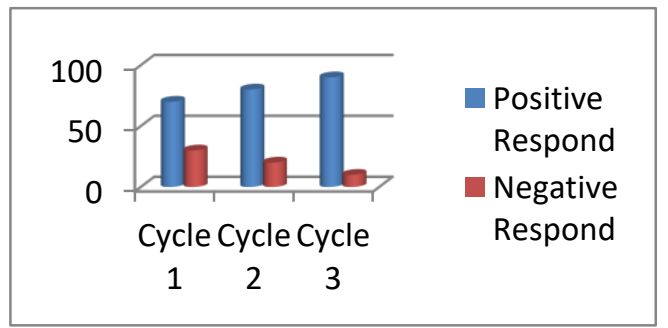

Based on table 3 and grafic 3 respond motivation and interest of students showed that the speaking English learning by using the contextual storytelling method gets positive respond of students. It proved that in cycle 170 $\%$ increase becoming $80 \%$ in cycle 2 and increase $90 \%$ in cycle 3 . It is said that

\section{CONCLUSION}

The result of Classroom Action Research in learning speaking English with the material narrative text on grade XII Science 6 Senior High School State 7 Manado by using Contextual Storytelling method can be concluded as follows:

1. The use of contextual storytelling method in learning speaking English can increase the mean score of performance test result, 65 in cycle 1 becomes 75 in cycle 2, and increases 80 in cycle 3 . The percentage of students who achieve the minimal score increase from $60 \%$ in cycle 1 becoming $70 \%$ in cycle 2 , and increase $90 \%$ in cycle 3 . It increases $30 \%$ from cycle 1 to cycle 3 .

2. Contextual storytelling method can increase the motivation and interest of students in learning speaking English. It can be proved with the percentage of students who gives positive respond to their motivation and interest in learning speaking English that $70 \%$ in cycle 1 becomes $80 \%$ in cycle 2 and increases 90 $\%$ in cycle 3 .

3. Contextual storytelling method is able to train students' skill to communicate with others and it can grow self confident and bravely in speaking English not just in school but with society.

4. This method can train students to learn individually in arranging and performing the imaginative story in English even to cooperate with others to achieve the learning goal.

5. Contextual storytelling method can prove the role of teachers as the source of information change becoming facilitator for the students through the sources of materials prepared by the teacher before.

Based on the achievement of research result that had been done, the researcher suggests:

1. To the English teachers to try applying contextual storytelling method in learning speaking English as the effort to increase the learning result and the motivation and interest of students in learning speaking English.

2. It is suggested to the English teachers to involve the students as many as possible in learning process so that they will feel that they are accepted and appreciated in learning activities to grow their motivation and interest so that they will be brave in learning speaking English to increase their performance result.

3. To the next researcher it is suggested to develop classroom action research by using contextual storytelling method in others topic. 


\section{REFERENCE}

Anderson, Mark \& Kathy. (1997). Text type in English Book 2. Australia: Macmillan.

Badan Standar Nasional Pendidikan. (2006). Standar Kompetensi dan Kompetensi Dasar Mata Pelajaran Bahasa Inggris Sekolah Menengah Atas dan Madrasah Aliyah. Jakarta: Depdiknas.

Hernowo. (2004). Bu Slim \& Pak Bil. Membincangkan Pendidikan di Masa Depan.Sepatan: MLC.

Johnson Elaine B. (2007). Contextual teaching and Learning. Bandung: MLC.

Me Kay\& Sandra Lee. (2002). The Reflective Teacher: A Guide to Classroom Research. Singapore: RELC.

Nana Sudjana. (2002). Dasar-dasar Proses Belajar Mengajar. Bandung: Sinar Baru.

Nurhadi. (2002). Pendekatan Kontekstual. Jakarta: Depdiknas.

Pardiyono. (2007). Teaching Genre BasedWriting. Jogyakarta: Andy.

Travers Robert M.W. (1977). Essentials of Learning. New York: Macmillan.

Sutaria. (1998). Vision \& Perfectives. Philipine: Education Manila Book Store.

Tilaar H.A.R. \& Riant Nugroho. (2008). Kebijakan Pendidikan. Yogyakarta: Pustaka pelajar.
Trianto. (2007). Model-Model Pembelajaran Inovative. Jakarta: Prestasi Pustaka Zainal Aqib. (2006). Penelitian Tindakan Kelas. Bandung: Irama Widya. 